\title{
The Habitat of 'Bacterium eurydice'
}

\author{
BY L. BAILEY \\ Rothamsted Experimental Station, Harpenden, Hertfordshire
}

(Received 20 September 1962)

\section{SUMMARY}

The alimentary canal of adult bees is the main source of 'Bacterium eurydice' which spreads between bees and to larvae, pollen and honey, from the mouths of infected adults. Most natural spread happens when foraging activity is greatest, probably because infected adults then collect and contaminate pollen which is soon eaten by the young broodrearing bees.

\section{INTRODUCTION}

'Bacterium eurydice' White (Achromobacter eurydice, Bergey's Manual, 1957) is usually abundant in honey-bee larvae with European foulbrood disease (White, 1920; Bailey, 1960) but its habitat has been givenas 'unknown' (Bergey's Manual, 1957). Reports of its presence in apparently healthy bees (Burri, 1947; Gubler, 1954) led us to study its incidence in normal colonies of bees and make observations to find its source.

\section{METHODS}

Medium. The following medium was used: glucose $1 \mathrm{~g}$.; yeast extract (Difco) $1 \mathrm{~g}$.; $\mathrm{KH}_{2} \mathrm{PO}_{4} 1.36$ g.; water $100 \mathrm{ml}$; adjusted to $\mathrm{pH} \mathrm{6.6}$ with $\mathrm{KOH}$, autoclaved at $116^{\circ}$ for $20 \mathrm{~min}$. and $5 \mathrm{ml}$. of $25 \%(\mathrm{w} / \mathrm{v}$ ) honey (previously acidified with $0.1 \%$, $\mathrm{v} / \mathrm{v}, \mathrm{H}_{3} \mathrm{PO}_{4}$ and autoclaved) then added. This honey broth was solidified when required with $2 \%$ agar to make honey agar. Unless stated otherwise, inoculated media were incubated anaerobically in McIntosh \& Fildes jars at 35 ${ }^{\circ}$. 'Bacterium eurydice' grows well in these conditions and contaminants were rare.

Bees. The part of the body to be examined was triturated, with sterile water when necessary, and inoculated to honey broth or pour-plates, or streaked on plates of honey agar. The identity of organisms growing in honey broth was examined by streaking on honey agar.

Live adult bees from ten widely separate parts of the British Isles, ranging from Kent and Cornwall to Yorkshire and Northern Ireland, were examined in March and May 1958. The other bees were from the Harpenden locality.

Pollen and honey. Pollen either as pollen-loads, each of about $20 \mathrm{mg}$. and freshly collected from local foraging bees, or equivalent amounts from stores in combs, was streaked on honey agar plates. Samples $(1 \cdot 0 \mathrm{ml}$.) of decimal dilutions of honey were inoculated into pour-plates of honey agar.

Flowers. Receptacles of flowers, on which local bees were working, were triturated (without perianths) in water and each inoculated into a pour-plate of honey agar.

\section{RESULTS}

Natural incidence of 'Bacterium eurydice'. Figure 1 summarizes results of observations in 1958 and 1959. Local adult bees and those from elsewhere at the same 
time of the year, showed the same proportion of infection. Table 1 shows that 'Bacterium eurydice' survived only a few days in stored pollen or honey.

Infection of caged bees in the laboratory. Groups of about 20 adult bees were maintained in small cages at $30^{\circ}$. The average length of life of individuals was about 3 weeks and each was replaced when it died by a bee from a normal colony. Such groups of bees remained infected indefinitely (at least 1 year) provided they were

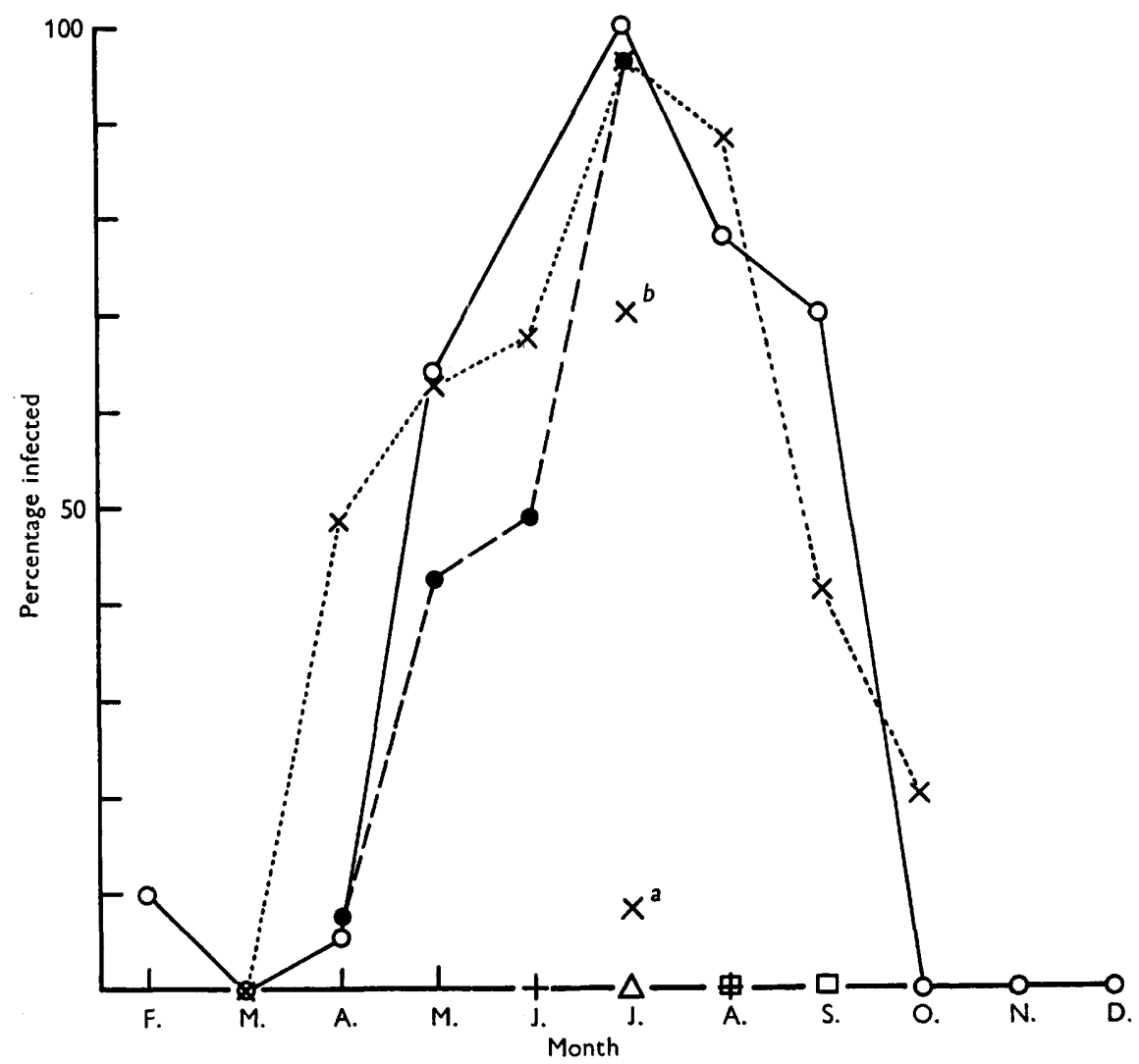

Fig. 1. The percentage of honey-bee adults and larvae, pollen loads and flower receptacles infected with 'Bacterium eurydice'. $O=$ adult bees (crops) (average of 26 bees per sample). $\quad \times=4$ - to 5-day-old larvae (mid-guts) (average of 127 larvae per sample). $x^{a}=2$ - to 3-day-old larvae (mid-gut) (30 larvae). $x^{b}=3$ - to 4-day-old larvae (midguts) (10 larvae). $=$ pollen loads (average of 58 loads/sample). $+=$ rectal contents of infected adult bees ( 6 bees/sample). $\square=$ newly emerged bees (crops) (12 bees/sample). $\triangle=$ receptacles of flowers: Trifolium repens, Rubus fructicosus, Sonchus oleraceus, Chamoenurion angustifolium, Lamium album; 10 of each.

supplied with solid food (a stiff paste of sucrose + water or honey), with water in a separate container. The surface of the food became heavily contaminated with 'Bacterium eurydice', and, according to plate counts, several thousand viable 'B. eurydice' organisms were regularly found in the head, mouthparts and crop of the bees; but this infection dwindled almost to nil within 14 days after the food was changed to sucrose solution or honey.

Newly emerged bees remained uninfected when they were kept separately. 
They acquired only slight infection (fewer than 100 bacteria per head) 6 days after they had been put with infected bees in cages containing solid food, whereas they became heavily infected (thousands of bacteria per head) within 6 days when they were separated from the infected bees (and their food) by a wire-gauze screen through which the infected bees fed them liquid food from their mouths. Attempts were made to infect newly emerged bees in cages by feeding them high concentrations of freshly isolated cultures of ' $B$. eurydice' in liquid food and on solid food, but all failed.

Table 1. Survival of 'Bacterium eurydice' in pollen and honey freshly stored by bees and subsequently kept at $18^{\circ}$

$\begin{array}{cr}\text { Material and date } & \\ \text { removed from bees } & \text { Date } \\ \text { Pollen, 4. June } & 4 \text { June } \\ & 9 \text { June } \\ & 11 \text { June } \\ \text { Honey, 13 July } & 13 \text { July } \\ & 27 \text { July }\end{array}$

Infection
14/21 samples infected
9/20 samples infected
0/20 samples infected
200-500 bacteria $/ \mathrm{ml}$.
0-8 bacteria $/ \mathrm{ml}$.

Characters of 'Bacterium eurydice'. Two general types of 'B. eurydice' were observed (Bailey, 1957): type 1 produced dense white colonies on honey agar; type 2 grew in coarsely granular colonies (Pl. 1, figs. 1, 2). Both types, which were isolated from adult and larval bees and pollen, grew well aerobically. Type 1, the commoner, produced gas in deep honey agar, and type 2 did not. Both grew aerobically on ordinary nutrient agar (Oxoid Nutrient Agar no. 2) + glucose or fructose, potato agar and wort agar. Good anaerobic growth with these media needed added glucose + fructose or honey, and even aerobic growth was sometimes feeble or delayed with them unless honey was added. Growth in deep agar, particularly without honey, was characteristically optimal from the subsurface to a few $\mathrm{mm}$. deep. Good growth, either anaerobic or aerobic, occurred in a Seitz-filtered extract of $10 \%(w / w)$ pollen (collected by bees) in water. Cells of both types of 'B. eurydice' were rods of varying length in honey broth or on honey agar (Pl. 1, fig. 4), whereas growth on nutrient agar, potato agar, wort agar and in pollen extract was frequently streptococcal in appearance (Pl. 1, fig. 5). Neither type grew in dilute honey $(2.5 \%, \mathrm{w} / \mathrm{w}$, buffered to $\mathrm{pH} 6.5$ with potassium phosphate), Apparently Gram positive in vivo, 'Bacterium eurydice' was Gram variable in vitro.

Bumble-bees. Bacteria that seemed to be types of 'Bacterium eurydice' were isolated from the heads of Bombus pratorum and B. agrorum. Like those from honey-bees, the anaerobic growth of these bacteria was much stimulated by honey and they grew as rods on honey agar or as streptococci in pollen extract, but their colonial form differed from those of the honey-bee types (Pl. 1, fig. 3).

\section{DISCUSSION}

The alimentary canal of adult bees, especially the anterior end, seems to be the only survival place for 'Bacterium eurydice', which does not persist in rectal contents of adult bees (Fig. 1), stored honey or pollen (Table 1), or larval faeces (Bailey; 1959). Newly emerged bees, and flowers recently visited by infected bees, are free from the organisms, so it seems to have no other natural means of survival. 
It is transmitted between adults by mouth; and larvae, honey and pollen are probably infected or contaminated by bacteria from the mouths of adults. The nutritional requirements of ' $B$. eurydice', other than carbohydrate, can be supplied by the bee, probably from the saliva, because large infections were maintained in caged bees given only solid carbohydrate as food and bees discharge saliva on such food to dissolve it (Simpson, 1960). 'B. eurydice' almost disappeared when bees were given liquid food, perhaps because little saliva was then produced. Some, possibly all, of the factors supplied by pollen extract for the in vitro growth of ' $B$. eurydice' may originate in bees, which add fluid from their mouths to pollen as they collect it (Butler, 1949). Natural populations of the bacterium probably increase first in bees collecting pollen and the bacterium is then transmitted to the young broodrearing bees which consume the pollen and from them to the larvae they feed. Thus, by July, when foraging and brood-rearing reaches its peak, infection becomes general. Pollen collection ends fairly abruptly at the end of July in the district where most of the observations were made. This probably accounts for the decline of infection in bees and larvae after this time. 'B. eurydice' soon dies in the stored pollen; the young bees, which eat it, are less infected than in summer, and old infected bees, which mostly eat honey, contain few bacteria, as they did in the cage experiments. The apparent loss of infectivity of ' $B$. eurydice' when grown in vitro suggests that it is closely adapted to its host. The bacteria in bumble-bees and honey-bees may be host specific: the only likely means of cross-infection would be through flowers, which do not become contaminated.

Thanks are expressed to Mr D. C. Lee for technical assistance.

\section{REFERENCES}

Banley, L. (1957). The isolation and cultural characteristics of Streptococcus pluton (Bacillus pluton White) and further observations on Bacterium eurydice. J. gen. Microbiol. 17, 39.

BatLey, L. (1959). An improved method for the isolation of Streptococcus pluton, and observations on its distribution and ecology. J. Insect Path. 1, 80.

BaILEy, L. (1960). The epizootiology of European foulbrood of the larval honey bee, Apis mellifera Linnaeus. J. Insect Path. 2, 67.

Bergey's Manual of Determinative Bacteriology (1957). 7th ed. Ed. by R. S. Breed, E. G. D. Murray \& N. R. Smith. London: Baillière, Tindall and Cox.

Burni, R. (1947). Die Beziehungen der Bakterien zum Lebenszyklus der Honigbiene. Schweiz. Bienenztg. 70, 273.

Butler, C. G. (1949). The Honeybee. Oxford: University Press.

GuBler, H. U. (1954). Bakteriologische Untersuchungen über gutartige Faulbrut der Honigbiene. Schreiz. Z. allg. Path. 17, 507.

Simpson, J. (1960). The functions of the salivary glands of Apis mellifera. J. Insect Physiol. 4, 107.

White, G. F. (1920). European foulbrood. Bull. U.S. Dep. Agric. no. 810.

\section{EXPLANATION OF PLATE}

Figs. 1, 2. The colonial forms of the two common types of 'Bacterium eurydice' from honey-bees. ( $\times 20$.

Fig. 3. Colonies of 'B. eurydice' from a Bombus sp. $\times 20$.

Fig. 4. Cells of 'B. eurydice' grown on honey agar. $\times 1000$.

Fig. 5. Cells of 'B. eurydice' grown in an extract of $10 \%(w / w)$, pollen in water. $\times 1000$. 

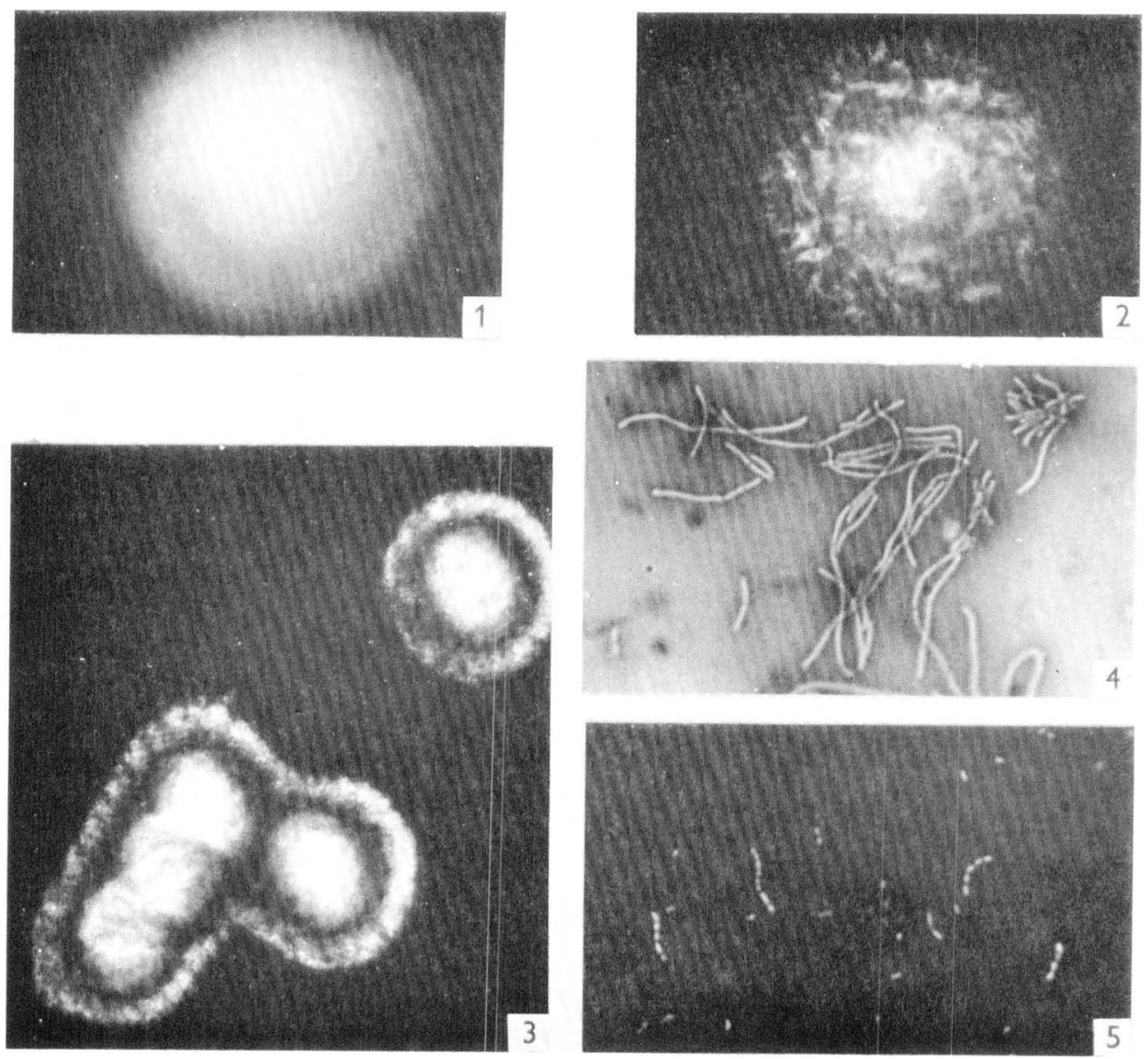